\title{
PENERAPAN PROJECT-BASED LEARNING DIPADU GROUP INVESTIGATION UNTUK MENINGKATKAN MOTIVASI, DAN HASIL BELAJAR MAHASISWA PENDIDIKAN BIOLOGI UNIVERSITAS MUHAMMADIYAH MALANG
}

\author{
Nasrul Hakim \\ Program Studi Pendidikan Biologi Universitas Jambi \\ e-mail: nasrul.bioum12@gmail.com
}

\begin{abstract}
This research to increase motivation and learning outcomes of students Biology Education semester VB at the University of Muhammadiyah Malang Environmental Sciences courses through the implementation of Project Based Learning combined-based Lesson Study Group Investigation. This research is Classroom Action Research. The research approach used is qualitative approach, consisted of two cycles, each cycle consisting of the stages of the action plan, action, observation, and reflection. The approach taken is a qualitative descriptive approach.

The results showed that the application of PjBL combined GI can increase student motivation to learn. Attention components increased by $3.6 \%$, Relevance components increased by $6.3 \%$, Convidence component increased by $9.1 \%$, while the component Satisfaction increased by $2 \%$. Student learning outcomes also increased. Students who got an A increased from $29.3 \%$ in Cycle I to $48.8 \%$ in Cycle II. Students who receive a grade of $\mathrm{B}+$ indicates the number remains, which amounted to $46.3 \%$. In connection with that then, the percentage of students who scored B fell from $24.4 \%$ in Cycle I to $4.9 \%$ in Cycle II. Based on the results concluded that the application of learning models $\mathrm{PjBL}$ combined GI can increase student motivation and learning outcomes. It is therefore advisable to adopt a Biology professor model $\mathrm{PjBL}$ combined GI by Lesson Study because it has been shown to increase motivation and cognitive learning outcomes of students.
\end{abstract}

Keywords: Project Based Learning, Group Investigation, Lesson Study, motivation, and Learning Outcome.

\section{PENDAHULUAN}

Salah satu upaya yang dapat dilakukan oleh pendidik untuk mencapai keberhasilan pembelajaran yang sesuai dengan harapan adalah dengan memperhatikan mahasiswa, materi pelajaran, metode pembelajaran dan media pembelajaran yang tepat, sehingga dalam proses belajar mengajar perlu adanya pemilihan strategis yang sesuai dengan karakteristik mahasiswa. Pemilihan strategi pembelajaran yang tepat dapat memotivasi mahasiswa untuk belajar dan membangun pengetahuan mereka sendiri tanpa bergantung kepada dosen, yang dapat berdampak pada peningkatan hasil belajar mahasiswa. Penerapan model pembelajaran yang inovatif harus banyak dikembangkan sebagai upaya membantu mengatasi kesulitan belajar dan memperbaiki hasil belajar mahasiswa. Calon guru professional mensyaratkan kompetensi pedagogi, kompetensi profesi, kompetensi pribadi dan kompetensi sosial. Kompetensi profesional menyatakan bahwa guru harus menguasai keilmuan dan dapat melaksanakan penelitian bidang ilmu 
maupun pembelajaran. Memenuhi kompetensi profesional ini maka calon guru dipersiapkan untuk menguasai bidang ilmu biologi salah satunya adalah ilmu pengetahuan lingkungan.

Ilmu pengetahuan lingkungan adalah ilmu yang membahas lingkungan sebagai komponen utama dari ekosistem, tempat kehidupan manusia berlangsung. Ilmu lingkungan bersifat antroposentrik yang artinya mengkaji lingkungan dalam kepentingannya untuk kebutuhan hidup manusia. Lingkungan adalah segala sesuatu yang berada di luar manusia sebagai subyek kajian. Lingkungan merupakan tempat hidup dimana manusia mengambil sumberdaya untuk memenuhi kebutuhannya, namun lingkungan juga merupakan tempat sampah, dimana manusia membuang semua sisa sisa yang sudah tidak dipergunakannya. Lingkungan adalah sumberdaya bagi kehidupan manusia. Perubahan pola hubungan manusia dan lingkungannya inilah awal dari munculnya permasalahan lingkungan dan berakibat pada terjadinya petaka (bahaya) lingkungan.

Berdasarkan hasil observasi awal menunjukkan bahwa motivasi belajar mahasiswa masih rendah. Masih banyak mahasiswa yang pasif dalam kegiatan diskusi kelompok. Diskusi di dalam kelas hanya didominasi oleh sebagian mahasiswa saja. Terlebih ketika membahas berbagai permasalahan lingkungan yang terjadi dan upaya penyelesaiannya. Peningkatan motivasi belajar dalam upaya menyelesaikan permasalahan lingkungan dimungkinkan terwujud dengan diterapkannya lesson study dalam perkuliahan ilmu pengetahuan lingkungan yang dilaksanakan dengan metode Project based learning dipadu group investigation.
Salah satu cara untuk mengemas masalah yaitu melalui kerja proyek. Metode ini cukup menantang dan dianggap sebagai suatu alat yang efektif untuk membelajarkan mahasiswa secara aktif karena mereka didorong untuk tidak tergantung sepenuhnya pada guru, tetapi diarahkan untuk dapat belajar lebih mandiri. Metode pembelajaran berbasis proyek merupakan metode pembelajaran yang mengacu pada filosofis konstruktivisme, yaitu pengetahuan merupakan hasil konstruksi kognitif melalui suatu aktivitas mahasiswa yang meliputi keterampilan maupun sikap ilmiah sehingga mahasiswa dapat mengkonstruksi pengetahuannya sendiri dan bermakna melalui pengalaman yang nyata. Kerja proyek memuat tugas-tugas yang kompleks berdasarkan kepada pertanyaan dan permasalahan (problem) yang sangat menantang dan menuntut mahasiswa untuk merancang, memecahkan masalah, membuat keputusan, melakukan kegiatan investigasi, serta memberikan kesempatan kepada mahasiswa untuk bekerja secara mandiri.

Pembelajaran berbasis proyek merupakan bagian dari proses pembelajaran yang memberikan penekanan pada pemecahan masalah sebagai usaha kolaboratif dalam periode pembelajaran tertentu (Sunaryo, 2005). Pembelajaran ini dilaksanakan dengan melibatkan mahasiswa pada tugas-tugas kompleks dalam kelompok pembelajaran kooperatif. Dengan demikian dimungkinkan mahasiswa untuk bekerja secara mandiri dalam membentuk pembelajarannya dan memunculkannya dalam produk nyata.

Pembelajaran berbasis proyek membutuhkan suatu pendekatan pengajaran yang komperehensif di mana lingkungan belajar siswa perlu didesain agar siswa dapat melakukan 
penyelidikan terhadap masalah-masalah autentik, termasuk pendalaman materi pada suatu topik mata pelajaran, dan melaksanakan tugas bermakna lainnya. Biasanya pembelajaran berbasis proyek memerlukan beberapa tahapan dan beberapa durasi, tidak sekedar merupakan rangkaian pertemuan kelas, serta belajar kelompok kolaboratif. Proyek memfokuskan pada pengembangan produk atau unjuk kerja (performance), secara umum siswa melakukan kegiatan: mengorganisasi kegiatan belajar kelompok mereka, melakukan pengkajian atau penelitian, memecahkan masalah, dan mensintesis informasi (Corebima, 2009).

$$
\text { Group Investigasi }
$$

merupakan suatu perencanaan pengorganisasian kelas secara umum dimana siswa bekerja dalam kelompok kecil menggunakan inkuiri kooperatif, diskusi kelompok, dan perencanaan kooperatif dan proyek. model pembelajaran Group Investigation (GI) melibatkan siswa sejak perencanaan, baik dalam menentukan topik maupun cara untuk mempelajarinya melalui investigasi dan menuntut para siswa untuk memiliki kemampuan yang baik dalam berkomunikasi maupun dalam ketrampilan proses kelompok (group process skill). Para guru yang menggunakan model pembelajaran GI membagi kelas menjadi beberapa kelompok dengan beranggotakan 5 hingga 6 siswa dengan karakteristik yang heterogen. Para siswa memilih topik yang ingin dipelajari, mengikuti investigasi mendalam terhadap berbagai subtopik yang telah dipilih kemudian menyiapkan dan menyajikan suatu laporan di depan kelas secara keseluruhan (Kusnandar 2009).

Hasil belajar akan lebih bermakna jika pada saat belajar diikuti dengan sikap dan motivasi yang kuat, belajar dengan sungguh-sungguh dan bertanggung jawab. Agar sikap, motivasi, kesungguhan belajar dan tanggung jawab dapat terjaga maka iklim belajar yang mengarah perlu di ciptakan. Lesson Study (LS) adalah model pembinaan (pelatihan) profesi pendidik melalui pengkajian pembelajaran secara kolaboratif dan berkelanjutan berlandaskan prinsipprinsip kolegialitas yang saling membantu dan mutual learning untuk membangun komunitas belajar. Tahap pelaksanaan lesson study meliputi perencanaan (plan), pelaksanaan (do) dan refleksi (see). Kegiatan lesson study dilakukan oleh sekelompok dosen. Lesson study bisa juga dibelajarkan pada mahasiswa sebagai calon guru, karena pada dasarnya lesson study dilakukan secara berkala dan berkelanjutan dalam rangka meningkatkan kompetensi dan keprofesionalan guru secara bertahap.

Kegiatan lesson study dalam pembelajaran, selain sebagai upaya mengaktifkan mahasiswa, juga berdampak pada dosen dapat melakukan review terhadap kinerjanya. Melalui lesson study dengan Plan, Do, See, memungkinkan pengembangan kemampuan akademik mahasiswa yang sungguh-sungguh dan menumbuhkan sikap lebih berhati-hati dan bertanggung jawab dalam belajar karena dengan lesson study akan diobservasi dan direfleksi baik oleh mahasiswa observer maupun oleh dosen observer. Berdasarkan wawasan tersebut maka perlu dilaksanakan penerapan model pembelajaran Project based learning dipadu Group Investigation berbasis lesson study untuk meningkatkan motivasi dan hasil belajar kognitif mahasiswa semester V Prodi Pendidikan Biologi Universitas Muhammadiyah Malang. 


\section{METODE}

Jenis penelitian ini tergolong Penelitian Tindakan Kelas (Classroom Action Research) yaitu studi sistematis terhadap praktik pembelajaran dan hasil belajar siswa dengan melakukan tindakan tertentu Sukarnyana (2002 dalam Nurmaningsih, 2005). Pendekatan penelitian yang digunakan adalah pendekatan kualitatif. Penelitian ini terdiri dari dua siklus yang masingmasing siklus terdiri atas tahap-tahap rencana tindakan, pelaksanaan tindakan, observasi, dan refleksi. Pendekatan yang dilakukan adalah pendekatan deskriptif kualitatif.

Penelitian ini dilakukan di Universitas Muhammadiyah Malang pada semester ganjil bulan September sampai dengan Desember 2013. Dengan menyesuaikan jam matakuliah Pengetahuan Lingkungan kelas B semester V (lima) program studi Pendidikan Biologi. Subjek penelitian adalah mahasiswa kelas B program studi Biologi yang sedang mengambil matakuliah Pengetahuan Lingkungan sebanyak 41 mahasiswa.

Tabel 1 . Matrik Jenis Data, Sumber Data dan Instrumen Penelitian

\begin{tabular}{|l|l|l|}
\hline Jenis Data & \multicolumn{1}{|c|}{ Sumber Data } & \multicolumn{1}{c|}{ Instrumen } \\
\hline Motivasi & Aktivitas mahasiswa & Angket motivasi \\
\hline \multirow{3}{*}{ Hasil } & Hasil tes & Soal tes: bentuk soal uraian singkat \\
Belajar & Desain proyek & Lembar penilaian desain proyek \\
& Hasil proyek (produk) & Lembar penilaian produk \\
& Resume & Lembar penilaian resume \\
\hline
\end{tabular}

Analisis data dalam penelitian ini meliputi kegiatan mengelola data mentah, menyajikan data, menarik kesimpulan dan melakukan refleksi. Dalam penelitian ini data yang diperoleh berupa data motivasi, keterampilan berpikir, kesadaran metakognitif dan hasil belajar siswa. Selain itu juga diperoleh data pendukung tentang kegiatan dosen dan catatan lapangan. Untuk mengetahui persentase skor motivasi, keterampilan berpikir dan kesadaran metakognitif secara klasikal dapat dihitung dengan menggunakan rumus.

\section{HASIL DAN PEMBAHASAN}

\section{A. PjBL dipadu GI terhadap} Motivasi Belajar Mahasiswa

Berdasarkan data hasil observasi awal didapatkan bahwa motivasi belajar mahasiswa kelas V-B Pendidikan Biologi FKIP UMM dalam perkuliahan pengetahuan lingkungan masih rendah. Motivasi belajar mahasiswa mengalami peningkatan pada Siklus I dan Siklus II. Secara lengkap persentase skor motivasi belajar mahasiswa per siklus sebagaimana dapat dilihat pada Tabel 2 berikut.

Tabel 2: Rerata Nilai Aspek Motivasi (\%) persiklus dan peningkatannya

\begin{tabular}{lccc}
\hline \multicolumn{1}{c}{$\begin{array}{c}\text { Aspek } \\
\text { Motivasi }\end{array}$} & Siklus I & Siklus II & Peningkatan $(\%)$ \\
\hline Attantion & & & 3,6 \\
Relevance & 78,7 & 82,3 & 6,3 \\
Convidence & 82,5 & 88,8 & 9,1 \\
Satisfaction & 71,2 & 80,3 & 2 \\
\hline \multicolumn{1}{c}{ Kategori } & 78,7 & 80,7 & \\
\hline
\end{tabular}


Persentase skor motivasi setiap komponen atau aspek motivasi mengalami peningkatan dari observasi awal ke Siklus I. Persentase skor motivasi juga mengalami peningkatan dari Siklus I ke Siklus II. Komponen Attention meningkat dari $78,7 \%$ pada Siklus I menjadi $82,3 \%$ pada Siklus II. Sehingga - Komponen Komponen Attention meningkat sebesar 3,6\%. Komponen Relevance meningkat dari $82,5 \%$ pada Siklus I menjadi $88,8 \%$ pada Siklus II. Sehingga persentase Relevance meningkat sebesar $6,3 \%$. Komponen Convidence meningkat dari $71,2 \%$ pada Siklus I menjadi $80,3 \%$ pada Siklus II. Sehingga persentase Convidence mengalami peningkatan sebesar $9,1 \%$. Sementara itu komponen Satisfaction meningkat dari 78,7\% pada Siklus I menjadi $80,7 \%$ pada Siklus II. Sehingga persentase Satisfaction mengalami peningkatan sebesar $2 \%$.

Untuk lebih memudahkan dalam melihat peningkatan komponen atau aspek motivasi setiap siklusnya maka dapat digambarkan dalam diagram batang pada Gambar 1 berikut.

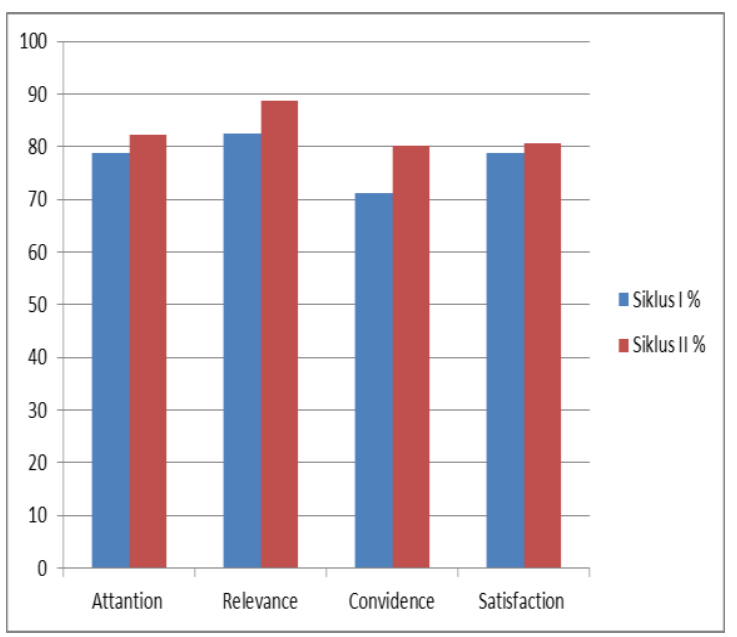

Gambar: Peningkatan Persentase Skor Motivasi Belajar Mahasiswa Per Siklus
Berdasarkan Tabel 2 dan Gambar 1 dapat dikatakan bahwa semua aspek mengalami peningkatan dan bahkan memenuhi kriteria sangat baik pada Siklus II. Hal ini berarti bahwa penerapan pembelajaran $\mathrm{PjBL}$ dipadu GI dapat meningkatkan motivasi mahasiswa kelas VB pada Matakuliah Pengetahuan Lingkungan Prodi Pendidikan Biologi Universitas Muhammadiyah Malang.

Model pembelajaran berbasis proyek (PjBL) merupakan suatu model pembelajaran yang menyangkut pemusatan pertanyaan dan masalah yang bermakna, pemecahan masalah, pengambilan keputusan, proses pencarian berbagai sumber, pemberian kesempatan kepada anggota untuk bekerja secara kolaborasi, dan menutup dengan presentasi produk nyata. Prinsip yang mendasari adalah bahwa dengan aktivitas kompleks ini, kebanyakan proses pembelajaran yang terjadi tidak tersusun dengan baik. Pembelajaran berbasis proyek juga dapat meningkatkan keyakinan diri para siswa, motivasi untuk belajar, kemampuan kreatif, dan mengagumi diri sendiri (Santyasa, 2006).

Berdasarkan hasil penelitian yang telah dilakukan, Mahanal (2009) mengemukakan bahwa PjBL memotivasi peserta didik untuk memperoleh pengetahuan melalui pelibatan tugas-tugas kognitif autentik dan memotivasi peserta didik dalam proses-proses pembelajaran selanjutnya. Sejalan dengan hasil penelitian Thomas (2000) bahwa PjBL dapat meningkatkan pencapaian prestasi akademik, pemahaman yang mendalam terhadap bahan ajar, dan meningkatkan motivasi belajar. Hasil kajian yang dilakukan Departemen Pendidikan Amerika Serikat (ED) dalam SSME (2006) menunjukkan adanya pengaruh 
positif tugas-tugas pembelajaran $\mathrm{PjBL}$ terhadap motivasi belajar peserta didik.

Hasil penelitian Dopplet (2003) juga menunjukkan PjBL mampu meningkatkan motivasi peserta didik dan memberikan gambaran tersendiri dalam semua tingkatan. Serupa dengan di atas, Munawaroh (2012) menuliskan bahwa dalam penelitian yang dilakukan di mana membuat alat peraga, diskusi kelompok, dan presentasi kelompok terlihat lebih menarik dibandingkan kelas kontrol, karena pada kelas eksperimen siswa mampu menghasilkan alat peraga perubahan energi, sehingga mampu meningkatkan motivasi siswa saat melakukan diskusi kelompok dan presentasi alat peraga.

Sementara itu, Moursund dkk (1997) meneliti sejumlah artikel tentang proyek di kelas yang dapat dipertimbangkan sebagai bahan testimonial terhadap pendidik, terutama bagaimana pendidik menggunakan proyek dan persepsi mereka tentang bagaimana keberhasilannya. Atribut keuntungan dari $\mathrm{PjBL}$ salah satunya adalah meningkatkan motivasi. Laporan-laporan tertulis tentang proyek itu banyak yang mengatakan bahwa peserta didik tekun bahkan sampai melewati batas waktu dan mereka berusaha keras dalam mengerjakan proyek. Pendidik juga melaporkan perkembangan dalam kehadiran dan berkurangnya keterlambatan peserta didik. Peserta didik melaporkan bahwa belajar dalam proyek lebih fun daripada komponen kurikulum yang lain.

Dengan menerapkan model pembelajaran group investigation, siswa merasa senang dan antusias, sehingga dikatakan memiliki motivasi yang baik. Siswa turut terlibat aktif dalam setiap langkah pembelajaran. Dengan adanya penggunaan media benda nyata dalam pembelajaran, membuat siswa semakin memahami dan memiliki antusiasme yang tinggi dalam mengamati dan menganalisis setiap topik yang didapatkan oleh kelompok. Siswa merasa lebih nyaman untuk bertukar pikiran dengan teman-temannya di dalam kelompok dalam memecahkan permasalahan. Hal ini sesuai dengan pendapat Sharan (1990) dalam Isjoni (2010), yang menyatakan bahwa belajar dengan model Cooperative Learning akan memiliki motivasi yang tinggi, karena didorong dan didukung oleh teman sebaya, dalam hal ini Group Investigation termasuk model pembelajaran Cooperative Learning.

\section{B. PjBL dipadu GI terhadap Hasil Belajar Kognitif Mahasiswa \\ Menurut Dimyati (2010) hasil} belajar adalah hasil yang telah diperoleh siswa berdasarkan pengalamanpengalaman atau latihan-latihan yang diikutinya selama pembelajaran. Berdasarkan data hasil analisis dapat dikatakan bahwa hasil belajar mahasiswa mengalami peningkatan jika kita membandingkan Siklus I dan Siklus II. Secara lengkap peningkatan hasil belajar mahasiswa per siklus sebagaimana dapat dilihat pada Tabel 3 berikut. 
Tabel 3: Persentase Hasil Belajar Mahasiswa Per Siklus

\begin{tabular}{|c|c|c|c|c|}
\hline \multicolumn{2}{|c|}{ SIKLUS I } & \multicolumn{2}{c|}{ SIKLUS II } \\
\hline NILAI & JUMLAH & \% & JUMLAH & \% \\
\hline A & 12 & 29,3 & 20 & 48,8 \\
\hline B+ & 19 & 46,3 & 19 & 46,3 \\
\hline B & 10 & 24,4 & 2 & 4,9 \\
\hline C+ & 0 & 0 & 0 & 0 \\
\hline C & 0 & 0 & 0 & 0 \\
\hline D & 0 & 0 & 0 & 0 \\
\hline E & 0 & 0 & 0 & 0 \\
\hline$\sum$ & 41 & 100 & 41 & 100 \\
\hline
\end{tabular}

Berdasarkan Tabel 3 diketahui bahwa ketuntasan belajar menunjukkan angka $100 \%$ pada Siklus I dan II. Mahasiswa yang mendapat nilai A meningkat dari $29,3 \%$ pada Siklus I menjadi $48,8 \%$ pada Siklus II. Mahasiswa yang mendapat nilai $\mathrm{B}+$ menunjukkan angka tetap, yakni sebesar $46,3 \%$. Sehubungan dengan itu maka, persentase mahasiswa yang mendapat nilai B turun dari $24,4 \%$ pada Siklus I menjadi $4,9 \%$ pada Siklus II.

Untuk lebih memudahkan dalam melihat peningkatan hasil belajar mahasiswa setiap siklusnya maka dapat digambarkan dalam diagram batang pada Gambar berikut.

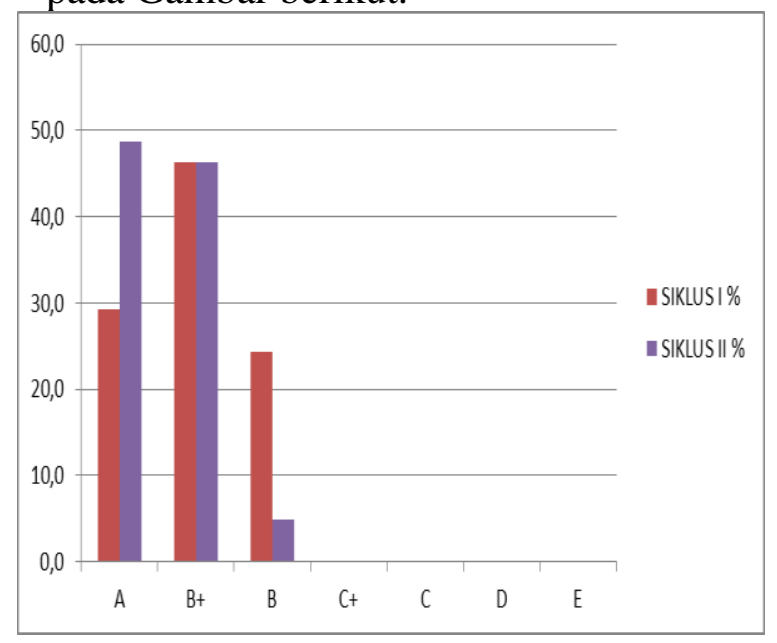

Gambar 2 Peningkatan Persentase Hasil Belajar Mahasiswa Per Siklus
Berdasarkan Tabel 3 dan Gambar 2 dapat dikatakan bahwa semua mahasiswa mengalami ketuntasan belajar. Hal ini berarti bahwa penerapan pembelajaran $\mathrm{PjBL}$ dipadu GI dapat meningkatkan hasil belajar mahasiswa kelas VB pada Matakuliah Pengetahuan Lingkungan Prodi Pendidikan Biologi Universitas Muhammadiyah Malang.

Hasil belajar dipengaruhi oleh pengalaman subjek belajar dengan dunia fisik dan lingkungannya. Sesuai dengan Standar Kompetensi Lulusan, sasaran pembelajaran mencakup pengembangan ranah sikap, pengetahuan, dan keterampilan yang dielaborasi untuk setiap satuan pendidikan. Ketiga ranah kompetensi tersebut memiliki lintasan perolehan (proses psikologis) yang berbeda. Sikap diperoleh melalui aktivitas menerima,menjalankan, menghargai, menghayati, dan mengamalkan. Pengetahuan diperoleh melalui aktivitas mengingat, memahami, menerapkan, menganalisis, mengevaluasi, mencipta. Keterampilan diperoleh melalui aktivitas mengamati, menanya, mencoba, menalar, menyaji, dan mencipta (Permendikbud, 2013).

Menurut Handayani (2011) berdasarkan hasil analisis penelitian yang dilakukan tentang tentang hasil belajar siswa dengan mengunakan metode pembelajaran $S T A D$ maka dapat 
disimpulkan bahwa, hasil belajar peserta didik secara klasikal sudah mencapai standar yang telah ditetapkan pada siklus I sebesar $63.3 \%$ pada siklus II menunjukkan hasil belajar sebesar 83,3\%. Penelitian Oktavia (2008) juga memberikan kesimpulan yang hampir sama yaitu Penerapan pembelajaran kooperatif STAD dengan pendekatan PBM dapat meningkatan hasil belajar biologi siswa kelas X SMA Negeri I Pakong Pamekasan. Rerata selisih skor antara pre-test dan post-test sebesar 25,58 pada siklus I, dan pada siklus II selisih antara pre-test dan post-test sebesar 18,67 dan 34,65 pada siklus III; ketuntasan belajar siswa sebesar 52,94\% (kurang) pada siklus I meningkat menjadi 73,53\% (baik) pada siklus II dan meningkat lagi menjadi $88,24 \%$ (sangat baik) pada siklus III.

Temuan penelitian ini juga sejalan dengan Hutasuhut (2010), hasil penelitian yang dilakukannya menunjukkan bahwa penerapan $\mathrm{PjBL}$ dapat meningkatkan motivasi dan hasil belajar mata kuliah Pengantar Ekonomi Pembangunan pada mahasiswa jurusan Manajemen FE Unimed. Ketuntasan belajar dapat diperoleh pada siklus II dari dua siklus yang direncananakan. Sementara itu, Gangga (2013) Artikel ini ditulis untuk mendeskripsikan penerapan $\mathrm{PjBL}$ dapat meningkatkan motivasi dan hasil belajar perbaikan ringan rangkaian kelistrikan kelas XI TOSM 1 kompetensi keahlian teknik otomotif Sepeda Motor SMKN I Koto XI Tarusan.

Hasil penelitian Thomas (2000) menunjukkan bahwa hasil belajar siswa menggunakan model Project Based Learning naik hampir $26 \%$ dibandingkan sekolah kontrol dan ada peningkatan yang signifikan kemampuan memecahkan suatu masalah antara pretes dan postes untuk kelas eksperimen menggunakan $\mathrm{PjBL}$.
PjBL dapat meningkatkan hasil belajar siswa, meningkatkan aktivitas dan keterlibatan siswa dalam pembelajaran, menumbuhkan kreativitas dan karya siswa, lebih menyenangkan, bermanfaat serta lebih bermakna (Purworini, 2006).

Karena perolehan hasil belajar pada siklus I dijadikan pengalaman oleh siswa untuk perbaikan di siklus II. Hal tersebut sejalan dengan pendapat Rifa'i dan Anni (2009) yang menyatakan bahwa hasil belajar merupakan perubahan perilaku yang diperoleh peserta didik setelah mengalami belajar. Jadi hasil belajar yang diperoleh oleh siswa terjadi setelah mereka melewati pembelajaran pada siklus I, dan mengalami peningkatan pada siklus II.

\section{PENUTUP}

Berdasarkan data hasil penelitian dapat disimpulkan sebagai berikut. Penerapan model pembelajaran PjBL dipadu GI dapat meningkatkan motivasi mahasiswa semester VB pada Matakuliah Pengetahuan Lingkungan Prodi Pendidikan Biologi Universitas Muhammadiyah Malang. Secara keseluruhan motivasi belajar mahasiswa meningkat sebesar $11 \%$ Persentase Attention meningkat 3,6\%. Persentase Relevance meningkat $6,3 \%$. Persentase Convidence meningkat $9,1 \%$. Persentase Satisfaction meningkat $2 \%$. Penerapan model pembelajaran PjBL dipadu GI dapat meningkatkan hasil belajarn kognitif mahasiswa semester VB pada Matakuliah Pengetahuan Lingkungan Prodi Pendidikan Biologi Universitas Muhammadiyah Malang. Hasil belajar kognitif mahasiswa mengalami peningkatan sebesar $2,1 \%$. Mahasiswa yang mendapat nilai A meningkat dari $29,3 \%$ pada Siklus I menjadi $48,8 \%$ pada Siklus II. Mahasiswa yang mendapat nilai $\mathrm{B}+$ tetap berjumlah $46,3 \%$ sedangkan 
mahasiswa yang mendapat nilai $B$ menurun jumlahnya dari $24,4 \%$ pada siklus I menjadi 4,9\% pada siklus II.

Penelitian ini tentu masih banyak kekurangan. Saran dari peneliti untuk penelitian lebih lanjut adalah sebagai berikut. Perlu penelitian lebih lanjut terutama untuk melihat motivasi dan hasil belajar kognitif berdasarkan pengamatan langsung atau berdasarkan aktivitas yang dilakukan mahasiswa selama proses pembelajaran (tidak hanya menggunakan angket yang diisi sendiri oleh mahasiswa) sehingga data lebih berimbang atau valid. Dalam pelaksanaan proyek, sangat dibutuhkan pendampingan dari dosen/guru agar pelaksanaan proyek sesuai dengan design yang telah direncanakan dan semua naggota kelompok terlibat aktif dalam pelaksanaan proyek. Perlu adanya pengelolaan kelas yang lebih baik terutama dalam mengatasi mahasiswa yang sering membuat ramai dan gaduh, sehingga pelaksanaan kegiatan pembelajaran dapat berjalan dengan baik dan lancar.

\section{DAFTAR RUJUKAN}

Anderson, L. W. \& Krathwohl, D. R. 2001. A Taxonomy For Learning, Teaching, And Assesing A Revision Of Bloom's Taxonomy Of Educational. New York: Addison Wesley Longman.

Arikunto, S. 2001. Prosedur Penelitian (Suatu Pendekatan Praktek). Jakarta: PT. Rineka Cipta.

BSNP. 2006. Panduan Penyusunan Kurikulum Tingkat Satuan Pendidikan Jenjang Pendidikan Dasar dan Menengah. Jakarta: BSNP.

Badan Standar Nasional Pendidikan. 2006. Standar Isi untuk Satuan Pendidikan Dasar dan Menenngah. Jakarta: BSNP
Budiharjo, A. H. 2010. Peran LPTK dalam Pengembangan Pendidikan Vokasi di Indonesia. Makalah dipresentasikan pada Seminar Internasional Peran LPTK dalam Pengembangan Pendidikan Vokasi di Indonesia, APTEKINDO, 2010.

Corebima, A.D. 2011. Berdayakan Kemampuan Berpikir dan Kemampuan Metakognitif Selama Pembelajaran. Makalah Seminar. Malang: Jurusan Biologi FMIPA UM.

Depdiknas. 2004. Pedoman Khusus Pengembangan Sistem Penilaian Berbasis Kompetensi SMP. Jakarta: DEPDIKNAS.

DIKTI. 2008. Buku Panduan Pengembangan Kurikulum Berbasis Kompetensi Pendidikan Tinggi (Sebuah Alternatif Penyusunan Kurikulum). Jakarta: Direktorat Akademik, Direktorat Jenderal Pendidikan Tinggi.

Dimyati \& Mudjiono. 2002. Belajar dan Pembelajaran. Jakarta: Dirjen Pendidikan Tinggi DEPDIKBUD.

Handayani, R. 2011. Penerapan Model Pembelajaran Kooperatif Tipe STAD (Student Teams Achievement Division) untuk Meningkatkan Hasil Belajar Siswa pada Materi Memahami Keanekaragaman Makhluk Hidup pada Kelas VII-C di SMP Muhammadiyah $06 \quad$ Dau Malang. $\quad$ Skripsi tidak diterbitkan. Malang: FKIP UMM.

Howard, J. B. 2004. Metacognitif Inquiry. School of Education Elon University (online) (http://www.ncsall.net/fileadmin /resources/ann_rev/rall_v5_ch7 
supp.pdf), diakses tanggal 9 Januari 2011.

Hutasuhut, S. 2010. Implementasi Pembelajaran Berbasis Proyek (Project-Based Learning) Untuk Meningkatkan Motivasi dan Hasil Belajar Mata Kuliah Pengantar Ekonomi Pembangunan pada Jurusan Manajemen FE UNIMED. Pekbis Jurnal, Vol.2, No.1, Maret 2010: 196-207.

Karyana, N. 2013. Meningkatkan Kemampuan Berpikir Kritis Melalui Penggunaan Metode Studi Kasus. Bandung: Widyaiswara LPMP Jawa Barat. Kemdikbud. 2013. Model Pembelajaran Berbasis Proyek (Project Based Learning). Jakarta: Kementerian Pendidikan dan Kebudayaan.

Mahanal, S. 2009. Pengembangan Perangkat Pembelajaran Deteksi Kualitas Sungai dengan Indikator Biologi Berbasis Konstruktivistik untuk Memberdayakan Berpikir Kritis dan Sikap Siswa SMA terhadap
Ekosistem Sungai di Malang.

Disertasi tidak diterbitkan.

Malang: Program Pasca Sarjana

Universitas Negeri Malang.

Moursund, D., Bielefeldt, T., Ricketts, R. \& Underwood, S. 1995.

Effect Practice: Computer

Technology in Education.

Eugene, OR: ISTE.

Munawaroh, R., Subali, B. \& Sopyan,

A. 2012. Penerapan Model

Project Based Learning untuk

Membangun Empat Pilar

Pembelajaran Siswa SMP.

Unnes Physics Education Journal (UPEJ), 1(1): 33-37.

Oktavia, S. 2008. Penerapan Pembelajaran Kooperatif STAD Melalui Pendekatan Pembelajaran Berbasis Masalah (PBM) untuk Meningkatkan Aktivitas dan Hasil Belajar Biologi Siswa Kelas X-3 SMA Negeri I Pakong Pamekasan Madura. Skripsi tidak diterbitkan. Malang: FMIPA Universitas Negeri Malang. 
Jurnal BIODIK Volume I Nomor 1 September 2015 